\title{
The Impact of Transformational Leadership on Job Satisfaction and Employee Turnover Intentions: A Conceptual Review
}

\author{
Evelyn Gan $^{1 *}$ and Mung Ling Voon ${ }^{1}$ \\ ${ }^{1}$ School of Business, Faculty of Business, Design and Arts, Swinburne University of Technology \\ Sarawak Campus
}

\begin{abstract}
All employees deserve a decent working environment in order to be productive in their work. High employee turnover has adverse effects on economic growth as companies incur additional costs and experience drop in productivity. Hence, identifying the factors that reduce employee turnover intention is in line with Sustainable Development Goals. This review paper aims to improve our understanding of the relationship between transformational leadership style and job satisfaction, and examines their impact on reducing employee turnover intention. The literature review has proved that transformational leadership and job satisfaction greatly influence an employee's decision to leave or stay with his or her organisation. Based on the literature, this paper also provides recommendations for future research areas that would provide valuable information in helping organisations reduce employee turnover intention, and ultimately employee turnover.
\end{abstract}

Keywords: transformational leadership, job satisfaction, employee turnover intentions, leadership style

\section{Introduction}

Leadership style and job satisfaction are recognised in the literature to be among the most powerful influences on employee turnover decisions (Buchanan, 2006; Lambert, Lynne Hogan, \& Barton, 2001; Noureen \& Abbas, 2017; Sakiru, Othman, Silong, Silva, \& Kareem, 2013; Tett \& Meyer, 1993b; Van Dick et al., 2004a).

\footnotetext{
* Corresponding author: evelyngan@gmail.com
} 
Leadership is fundamental to the development of society, organisations and individuals (Bass, 1997). Not surprisingly, the impact of leadership on employee performance has also attracted significant research interest (Sakiru et al., 2013). Literature suggests that leaders play a key role in motivating employees, developing skills, and providing a conducive work environment. These elements help improve employee job satisfaction, which leads to lower turnover intention (Buchanan, 2006). Hence, Sakiru et al. (2013) suggested that the failure or success of any organisation is dependent on its leader. The leadership style of leaders has, therefore, received a lot of research attention and is undeniably a crucial element in organisational success in retaining employee talent (Sakiru et al., 2013). Furthermore, researchers, such as Khalid, Pahi and Ahmed (2016), have suggested that the significant role of leadership in reducing employee turnover is attributed to the fact that leaders, by virtue of their position, have a strong influence on employees' decisions to remain with or leave an organisation. Even though multiple factors may affect employee turnover intentions, leadership style has been shown to have a significant effect on employee decisions to stay in or quit their jobs (Alatawi, 2017).

Apart from leadership, another major influence on employee turnover is job satisfaction. Satisfied employees feel motivated, leading to lower job turnover. In contrast, a dissatisfied employee is likely to seek alternative opportunities, leading to higher job turnover (Aguiar do Monte, 2012). Several theories posit that employees who dislike their jobs either seek to permanently leave or temporarily avoid work through absenteeism or arriving late. The key motivation for these withdrawal behaviours is poor job satisfaction (Mobley, 1977) because an employee's intention to leave is the next logical step after experiencing dissatisfaction in his or her job. Current research suggests that high levels of job satisfaction have a negative relationship with employee turnover intentions (Spector, 1997) and that job satisfaction is considered one of the most accurate predictors of employee turnover intentions (Cotton \& Tuttle, 1986; Lambert et al., 2001; Meyer, Allen, \& Smith, 1993; Noureen \& Abbas, 2017; Smith \& Shields, 2013; Spector, 1997; Van Dick et al., 2004a).

High employee turnover has negative impacts on organisational productivity and performance through the disruption of work, and additional recruitment, selection, and training costs. Therefore, low employee turnover should be a priority for any organisation (Alatawi, 2017). Research into the costs of employee turnover has suggested that only a small portion, $15-30 \%$, is actual direct costs (e.g. recruitment, advertising, and training). The remaining $70-85 \%$ is typically not captured in a company's balance sheets, but includes lowered productivity, knowledge loss and demotivation of remaining employees (Racz, 2000). In particular, the loss of employees with firm-specific expertise, which is hard to imitate and non-transferable, affects organisational performance and competitive advantage. In addition, an organisation's return on investment in human capital is significantly reduced (De Winne, Marescaux, Sels, Van Beveren, \& Vanormelingen, 2018). The current research indicates that although turnover can never, or should, be completely eliminated, organisations should aim to minimise it, particularly among employees with firm-specific knowledge (Robbins \& Coulter, 2012). A small amount of turnover benefits an organisation because development opportunities arise for other employees (De Winne et al., 2018).

The existing literature contains several studies that cover the impact of transformational leadership and job satisfaction on turnover intention separately. Although 
it is evident that both factors result in lower turnover intention, the linkage between leadership style and job satisfaction can be further clarified. Hence, this review paper aims to compile findings that also show how both leadership style and job satisfaction are linked to one another, which will enrich our understanding of the concepts of leadership style, in particular, transformational leadership, and job satisfaction along with their individual roles as well as the linkage between both elements in reducing employee turnover intention.

\section{Literature review}

\subsection{Historical overview and definitions of transformational leadership}

Of the different leadership styles presented in the literature, transformational leadership is characterised by envisioning, enabling, and empowering employees (Bass, 1997). The term transformational leadership was coined by Downton in 1973; however, its significant development only started when Burns (1978) introduced the concept following his study of famous political leaders. The transforming leader looks for potential motives in followers, seeks to satisfy higher needs, and engages the full person of the follower. The result of transforming leadership is a relationship of mutual stimulation and elevation that converts followers into leaders and may convert leaders into moral agents (Burns, 1978, p. 4).

He describes transformational leadership as a process in which leaders and followers both play a role in helping each other achieve higher levels of motivation. In particular, leaders lead by example and are able to inspire their followers to achieve beyond what is expected of them. In contrast, transactional leadership focuses on a "give and take" relationship and lacks any focus on inspiring followers (Burns, 1978). In contrast, Bass's (1985) transformational theory is that leadership goes beyond an achievement-reward relationship. A leader's focus is on moulding followers through intellectual stimulation and self-development and motivating followers to consider the good of the group (Howell \& Avolio, 1993).

Bass outlined three characteristics of transformational leadership theory: charisma, individualised consideration and intellectual stimulation (B. M. Bass, 1985). The theory was expanded by Bass (1997) to include four components: idealised influence (behaviour and attributes), inspirational motivation, intellectual stimulation and individualised consideration. Further refinement by B. M. Bass and Avolio (1993) resulted in a leadership model (FRLM) that consists of transformational, transactional and laissez-faire leadership behaviours. Deemed one of the best-formulated leadership models, FRLM covers almost all the leadership characteristics of leaders (Donald, 2017) and posits that leaders may exhibit a combination of leadership style characteristics, and not use one style exclusively. According to B. M. Bass and Avolio (1994), a true transformational leader motivates a positive outlook among workers, creates awareness of the organisation's mission or vision and encourages workers and followers to put the group's interest above their own.

Advocates of transformational leadership state that it provides a solution for leaders with followers who have a negative perspective of the organisation. Over time, a transformational leader may align organisational goals and individual goals through building a personalised and meaningful relationship with his or her followers, aligning followers' moral values, and guiding followers' behaviours. Furthermore, transformational leaders are able to adapt to the historical, social and economic environment, the type of organisation, the personality and values of the leader. In times of distress and rapid change, transformational leaders are more likely to develop new solutions together with their 
followers (B. M. Bass, 1985) because they have the ability to engage and motivate followers to achieve exceptional results. The three key things this type of leaders will do: they take heed of followers' concerns and career development; they give followers a fresh perspective by helping them view longstanding problems in a different way; and they get followers to go an extra mile and contribute to achieving the organisation's goals (Robbins $\&$ Coulter, 2012).

\subsection{Dimensions of transformational leadership}

The original transformational leadership model, developed by Bass and his colleagues in 1995, contained five dimensions:
1. Idealised influence (attributes)
2. Idealised influence (behaviour)
3. Inspirational motivation
4. Intellectual stimulation
5. Individualised consideration

Since then, researchers have classified transformational leadership into four dimensions (Avolio, Waldman, \& Yammarino, 1991; Kirkbride, 2006; Nemanich \& Keller, 2007), also called the four I's of transformational leadership (Avolio et al., 1991). The reduction to four dimensions is a result of idealised influence (both attributes and behaviour) being considered as only one dimension. Each of the four dimensions is discussed in detail:

\subsubsection{Idealised influence (charisma)}

According to B. M. Bass (1985), the most crucial concept of transformational leadership is charisma. It is not confined to the heads of organisations, but can be present at all levels of leadership in an organisation. Leaders who possess idealised influence are role models for other individuals in the organisation. Followers feel a sense of pride in being associated with their leaders, and try to be like them (B. M. Bass, 1998; Kirkbride, 2006). Burns (1978) outlined two ways that charismatic leaders influence followers: their personality and the values or ideas they uphold. Their personality traits allow them, according to B. M. Bass (1990), to motivate followers to undertake extra effort and achieve great things. Such leaders also consider the interests and needs of others above his or her own personal needs (B. M. Bass, 1985; B. M. Bass \& Avolio, 1994). Most importantly, leaders with idealised influence possess a clear vision and direction, and are prepared to take risks (B. M. Bass, 1998). A leader shares risks with his or her followers, acts consistently and with integrity, and avoids using power for personal benefit (B. M. Bass \& Avolio, 1994). Transformational leaders employ idealised influence to empower their followers, which increases their adaptability and ability to cope with changing conditions (Nemanich \& Keller, 2007).

\subsubsection{Inspirational motivation}

A leader with inspirational motivation first creates awareness of the team's and organisation's mission or vision. Although inspiration is of paramount importance, it is 
often an ignored aspect of leadership (B. M. Bass \& Avolio, 1994). According to Barnett, McCormick, and Conners (2001), inspirational motivation is closely linked with idealised influence. The presence of individualised consideration and intellectual stimulation, which underpin a leader's ability to make his or her followers feel valuable and confident, strengthens a leader's inspirational motivation (Avolio et al., 1991). Inspirational leaders exude behaviours that provide purpose and motivation to followers. They communicate their expectations clearly, set a positive outlook for the organisation's future, and show strong commitment to working with followers towards achieving a shared vision and goals (B. M. Bass, 1998; B. M. Bass \& Avolio, 1994). They also focus on longer term goals, and encourage and empower followers to achieve them (Howell \& Avolio, 1993). As a result, followers are motivated and driven to achieve more than they expect of themselves. Inspirational leaders also set an example through their own dedication to an organisation's goals and by communicating with followers, which promotes trust and follower loyalty to the organisation, even in difficult situations (Donald, 2017).

\subsubsection{Intellectual stimulation}

Leaders who exhibit this characteristic promote creativity among followers by encouraging them to question assumptions and approach old problems in new ways, which leads to the development of new ideas (Barnett et al., 2001; B. M. Bass \& Avolio, 1994; B. M. a. Bass, 2006; Nemanich \& Keller, 2007). These leaders encourage staff to challenge the status quo (B. M. Bass, 1985), never correct or criticise others publicly, which provides a safe environment for followers to develop creativity (B. M. Bass, 1998). Stimulated, followers critique issues and develop alternatives, resulting in new ways of completing tasks. This is particularly useful when the leader does not have much experience or information to solve the problem. Such an approach encourages creativity rather than conformity (Avolio et al., 1991), an openness to differing ideas (Donald, 2017), and a strong emphasis on problemsolving (B. M. Bass, 1990).

\subsubsection{Individualised consideration}

According to B. M. Bass (1985, p. 82), individualised consideration consists of two aspects. The first is to treat followers as unique individuals with needs. The second is to identify followers' weaknesses and strengths and support their development and growth (Barnett et al., 2001; Kirkbride, 2006). This is in line with Burns (1978, p. 4), who states, "The transforming leader looks for potential motives in followers, seeks to satisfy higher needs, and engages the full person of the follower." In essence, the leader is able to make their followers feel important and nurture them to achieve their greatest potential (B. M. Bass \& Avolio, 1993; Donald, 2017). A leader's charisma may attract followers to pursue a vision; however, individualised consideration is what stimulates followers to achieve their fullest potential (Yammarino \& Bass, 1990). Leaders who practise individualised consideration mentor followers to support their growth (B. M. Bass, 1990; B. M. a. Bass, 2006). Listening and empathy build an individual's confidence and promote self-development (Avolio et al., 1991), making followers committed to the leader, and holding a clear purpose that motivates them to exceed expectations. Through individualised consideration, 
leaders maximise the performance of both individuals and the organisation followers (Howell \& Avolio, 1993).

\subsection{Definitions of job satisfaction}

The literature shows multiple definitions of job satisfaction, meaning that it is undecided on whether job satisfaction is an attitude, feeling, belief, or value.

Hoppock (1935) comprehensive analysis of 32 studies on job satisfaction concluded that job satisfaction was "a combination of psychological, physiological and environmental circumstances that cause a person to truthfully say 'I am satisfied with my job"' (Hoppock, 1935, p. 47).

Other definitions view job satisfaction as a feeling. For example, job satisfaction has been described as how people feel about their jobs or the extent to which people are satisfied or dissatisfied with their jobs (Spector, 1997). Similarly, Newstrom and Davis (2002) defined job satisfaction as "a set of favourable or unfavourable feelings with which employees view their work." According to Locke (1969), job satisfaction was a happy emotion experienced by individuals who perceive that their job fulfils their job values. This definition emphasises that job satisfaction is unique to each individual. Job satisfaction starts with job values, what employees seek or desire from their job. This differs from one individual to another. For example, pay discrepancies may be more dissatisfying to one person than someone else who cares less about pay.

Conversely, Locke (1969) disagreed with definitions that equated values to expectations and needs: values are not synonymous with expectations and needs. The expectation is a belief of what may occur in the future, but the outcome may not be desirable to the individual. In contrast, what is valued may not be what is expected. Values tend to remain constant regardless of whether it is expected. Needs refer to what individuals need to survive. Unlike values, needs do not require awareness; they automatically arise when required. Hence, it is values rather than needs that determine an individual's actions and emotional responses. This view is supported by George (2012, p. 89), who stated that work values are "an employee's personal convictions about what outcomes one should expect from work and how one should behave at work". Work values are broad, longlasting beliefs that people contribute to how they experience their work. Although values, attitudes, moods, and emotions incorporate employee thoughts and feelings, work values are the strongest and affect the other elements. This suggests that work values have the strongest influence on job satisfaction.

Other definitions deem job satisfaction as a combination of attitudes, feelings, and beliefs. According to Armstrong (2006, p. 264), job satisfaction refers to the "attitudes and feelings people have about their work. Positive and favourable attitudes towards the job indicate job satisfaction. Negative and unfavourable attitudes towards the job indicate job dissatisfaction." In a similar vein, George (2012, p. 71) defines job satisfaction as "the collection of feelings and beliefs that people have about their current jobs. People's levels or degrees of job satisfaction can range from extreme satisfaction to extreme dissatisfaction."

Other authors have also placed emphasis only on attitude in defining job satisfaction. According to Weiss (2002, p. 175), job satisfaction is defined as an attitude, "a positive (or negative) evaluative judgment one makes about one's job or job situation." 
However, the author disagrees with job satisfaction definitions that equate feelings/effect to attitude. Job satisfaction is an attitude, not an affective reaction, which involves the evaluation of an attitudinal object using job satisfaction measures. On the other hand, emotions and moods vary as to the situation and have longer-term effects on individuals than the evaluative judgments. Van Dick et al. (2004b, p. 352) expressed the same view, suggesting to be "an attitude towards specific aspects of the concrete job and tasks one has to perform". Similarly, Ivancevich, Gibson, and Konopaske (2011, p. 102) defined job satisfaction as "the attitude that workers have about their jobs. It results from their perception of the job."

In a more recent definition by Moradi, Almutairi, Idrus, and Emami (2013), the concept of job satisfaction was deemed a more complex concept, comprising job characteristics, work environment, personal characteristics, and attitudes. However, all these environmental factors are dynamic, and change in any one of them affects job satisfaction.

\subsection{Definitions of turnover intention}

Employee retention, according to Khalid, Pahi, and Ahmed (2016), is defined as an organisation's ability to retain its employees. And retaining employees requires organisations to create an environment in which employees experience job satisfaction and to foster high organisational commitment.

George (2012, p. 85) defined employee turnover as the "permanent withdrawal of an employee from the employing organization". Hence, turnover intention, which is an antecedent to voluntary turnover, essentially starts when employees have thoughts of permanently leaving the organisation. Tett and Meyer (1993a, p. 262) described turnover intention as "a conscious and deliberate wilfulness to leave the organization". It is also defined as the degree to which employees intend to stop their membership with their organisations (Alatawi, 2017). For example, employees who do not plan on leaving have zero turnover intention.

\subsubsection{Validity of turnover intention as a predictor of actual turnover}

According to Harhara, Singh, and Hussain (2015), turnover intention is one of the most accurate predictors of employee turnover. Furthermore, it is widely accepted among researchers that the intention to stay or leave an organisation is the last cognitive stage in a voluntary turnover decision-making process. Hence, of the employee turnover models developed over the last two decades, most have incorporated turnover intention (Lambert et al., 2001). Further support for the validity of turnover intention is found in the theory of planned behaviour, which outlines how intentions, driven by motivational factors, affect behaviour. Generally, the stronger the intention to perform a behaviour, the higher the likelihood of executing it (assuming the behaviour is at one's will) (Ajzen, 1991). This principle can also be applied to turnover intention, whereby the stronger the turnover intention, the more likely the employee will quit. Research has also consistently found 
turnover intention to be a strong cognitive antecedent of actual turnover (Tett \& Meyer, 1993a).

Moreover, it has been argued that knowledge of an intention to quit is more valuable to employers than actual turnover. If factors contributing to the intention to quit can be addressed, the employer may change the employee's intention (Lambert et al., 2001). Similarly, Harris stated that investigating high turnover intention is more crucial than turnover itself. Not only can organisations avoid negative employee behaviours that might influence other colleagues, but they can also reduce actual turnover costs (Hughes, Avey, \& Nixon, 2010).

Finally, employee turnover is problematic to track. Alatawi (2017) noted that researchers who utilised actual employee turnover encountered challenges in following up with the individuals who left their organisations. Hence, the turnover intention is considered a more practical measure to be used for research purposes.

\subsection{Impact of transformational leadership on job satisfaction and turnover intention}

Contextual factors have been shown to moderate the impact of transformational leadership on both organisation and individuals. According to B. M. Bass (1985), transformational leaders are likely to be welcomed in organisations that are receptive to change and willing to take risks. However, organisations bound by bureaucracy may view transformational leaders, who often question the status quo, as a threat and inappropriate to the existing structure.

A significant base of evidence supports transformational leadership as a better style than transactional leadership. For example, studies that looked at managers in multiple work environments, including the military and business, reported that transformational leaders were evaluated as more effective performers, more promotable than their counterparts who exhibited transactional leadership, and possessed better interpersonal skills. Moreover, evidence shows that transformational leadership has a strong relationship with lower turnover rates and higher levels of productivity, employee satisfaction, creativity, goal attainment, follower well-being, and corporate entrepreneurship, particularly in start-up firms (Robbins \& Coulter, 2012).

According to the first study done by B. M. Bass (1985), transformational leaders have a positive impact on their employees' job satisfaction, particularly satisfaction with their leaders. The leader makes each employee feel special (through individualised consideration) and gives them the motivation to achieve their full potential (through idealised influence and inspirational motivation). Other studies have also reported a significant positive relationship between transformational leadership and job satisfaction (Berson \& Linton, 2005; Bono \& Judge, 2003; Nemanich \& Keller, 2007; Podsakoff, Mackenzie, \& Bommer, 1996). In view of the significant influence of leaders in determining an individual's overall job satisfaction, many studies have focused mainly on satisfaction with the leader; they have consistently found that transformational leaders have the strongest positive influence on followers' job satisfaction in comparison with other leadership styles (B. M. Bass, 1990; Bycio, Hackett, \& Allen, 1995; Dunham-Taylor, 1995; Koh, Steers, \& Terborg, 1995; Yammarino \& Bass, 1990). In fact, the positive impact of 
transformational leadership in generating higher satisfaction levels among employees has been consistently proven over two decades of research (Walumbwa, Lawler, Avolio, Wang, $\&$ Shi, 2005). Recent studies continue to provide evidence concerning the strong positive impact of transformational leadership on employees' job satisfaction as such leaders motivate followers to set higher standards and develop strategies to achieve them (Worthy, Dawson, \& Tavakoli, 2020).

Significant evidence exists in the extant research that transformational leaders reduce their followers' intention to quit. Transformational leaders foster employee loyalty to the organisation by encouraging employees to overcome obstacles and remain effective in their work. Support for this was found by Alatawi (2017), who noted that transformational leadership had a negative relationship with employee turnover intentions. In contrast, other leadership styles that set a narrow-minded vision experience high employee turnover with the remaining employees untalented or disengaged (Alatawi, 2017). Transformational leaders who promote a collaborative working culture create a sense of belonging and being valued among employees, which was found to reduce both turnover intention and actual turnover (Sun \& Wang, 2017). This continues to hold true in more recent research by Pravichai and Ariyabuddhiphongs (2018), who found that transformational leadership significantly reduces employee turnover intention.

Other researchers, such as Dupré and Day (2007), have found that transformational leaders have a significant positive impact on employee job satisfaction, which leads to lower turnover intentions. Employees, feeling supported by their leaders, finding purpose in their jobs, were less inclined to leave the organisation. Also, B. M. a. Bass (2006, p. 36) opined that effective transformational leaders decrease followers' intention to quit by demonstrating that "the goals and values of the group, follower, leader, and organization" are in alignment with one another. Hence, followers are less likely to quit as they regard the leader as a facilitator to achieve their personal goals, which are also aligned with those of the organisation. Moreover, followers who receive individual consideration from the leader feel their needs are met and will likely remain in the organisation. Similarly, Krishnan (2005) and Hughes et al. (2010) found a significant negative relationship between transformational leadership and subordinate's intention to quit.

Several dimensions of transformational leadership play a significant role. In particular, idealised influence (i.e. charisma) creates a desire among followers to be identified with the leader, motivating followers to remain in the organisation so long as the leader is there (Shamir, House, \& Arthur, 1993). Transformational leaders also "use inspirational motivation to build emotional commitment to a mission or goal" (B. M. a. Bass, 2006, p. 36). Followers with an emotional commitment to the leader and the organisation have lower intentions to quit.

However, since transformational leaders engage followers, often on an individual basis, employees whose jobs require minimal supervision may not be affected by this leadership style. For example, a study among academic staff in a Malaysian community college by Sang Long, Yean Thean, Wan Ismail, and Jusoh (2012) revealed an insignificant relationship between transformational leadership and academic staff turnover intention. The authors attributed this situation to the nature of academicians' work, whereby the majority of time is spent with students. They have minimal contact with their supervisors, and their teaching tasks are carried out with high autonomy. 


\subsection{Impact of job satisfaction on turnover intention}

Several theories posit that employees who dislike their jobs will shun them, either permanently by quitting or temporarily through absenteeism or arriving late. The key motivation for these withdrawal behaviours is a lack of job satisfaction. Hence, this infers that a high level of job satisfaction has a negative relationship with employee turnover intention (Spector, 1997).

Even in organisations with high job satisfaction, employee turnover exists. While extremely high levels of turnover are costly, some level of turnover is typical and in fact, benefits an organisation (Armstrong, 2006).

Several studies, such as Ivancevich et al. (2011), found a moderate correlation between job satisfaction and turnover intention. George (2012) reported a weak-tomoderate negative relationship between job satisfaction and turnover intention and suggested that high job satisfaction resulted in low turnover intention. One reason for this range in the relationship strength is that satisfaction may not be the ultimate determinant of turnover. It holds true that satisfied employees have a lower likelihood of quitting than dissatisfied employees. However, some dissatisfied employees never leave, and even satisfied employees may switch to another organisation in the future.

However, Mobley's turnover process model posits that the entire turnover process is triggered by job satisfaction Mobley (1977). Highly satisfied employees may never consider quitting; on the other hand, dissatisfied employees may consider quitting. Employees go through a process of assessing the costs of leaving versus the benefits of a new job. The costs may include employee entitlements tied to seniority, such as pension plans or job security, and from this, the employee develops an intention to quit or stay, which results in turnover behaviour. Clearly, other factors may also play a role in determining actual turnover: unless the benefits of a new job outweigh the costs of leaving, dissatisfied employees will remain in an organisation. A similar perspective is shared by Tae Heon, Gerhart, Weller, and Trevor (2008), whose study stated that job dissatisfaction was not the only cause of turnover. They recognised that even satisfied employees may leave due to a variety of reasons (e.g. better job offers, family reasons) and that dissatisfied employees may never quit.

Nevertheless, the literature has also shown that job satisfaction significantly impacts employee turnover intention. According to Lambert et al. (2001, p. 246), job satisfaction measures are "the most informative data a manager or researcher can have for predicting employee behaviour." Their study found that job satisfaction had the largest direct impact on turnover intention compared with other factors, alternative employment opportunities, financial rewards, tenure and age. Additionally, Van Dick et al. (2004b) study reported that job satisfaction is a widely researched predictor of turnover. They concluded that job satisfaction has a significant direct influence on turnover intention and is a strong predictor of actual turnover behaviour. Furthermore, earlier studies by Cotton and Tuttle (1986) and Tett and Meyer (1993a) validated job satisfaction as a significant predictor of turnover intention. These researchers identified high levels of satisfaction with lower levels of turnover intention, as did Smith and Shields (2013) who stated low levels of job satisfaction were a major concern for organisations as it is one of the main reasons for employee turnover. According to Noureen and Abbas (2017), a significant body of literature has suggested that job satisfaction is a predictor of both turnover intention and actual turnover. Moreover, recent research continues to support the importance of job 
satisfaction in reducing employee turnover intention. Park, Joaquin, Min, and Ugaddan (2018) found that when employees experienced job satisfaction, their turnover intention was reduced; on the other hand, dissatisfied employees exhibited a higher likelihood of quitting their jobs. In addition, a study by Matthews, Carsten, Ayers, and Menachemi (2018) revealed that employees' job satisfaction, coupled with a strong relationship with their supervisors, reduced employee turnover intention.

\section{Conclusion}

This paper has provided an overview of the characteristics of transformational leadership, along with the impacts of this leadership style and job satisfaction on employee turnover intention. The literature has provided evidence that the presence of transformational leadership and job satisfaction reduce employee turnover intention, which largely affects an employee's decision to stay with or leave the organisation. The findings provided in this paper serve as a stepping-stone for further research in the related areas. In particular, researchers may consider further research into the specific elements of transformational leadership to determine the extent to which each element affects turnover intention. In addition, further research can also be done to explore the predictors of job satisfaction, which will help organisations understand what keeps employees satisfied with their jobs. Finally, more research is needed on the relationship between turnover intention and actual turnover behaviour.

Based on a literature review, significant evidence confirms that transformational leadership and job satisfaction greatly influence an employee's decision to leave or stay with his or her organisation. The findings presented here hopefully enrich our understanding of transformational leadership and job satisfaction and their effects on employee turnover intention. Greater clarity around these important concepts should enable organisations to identify and groom effective leaders and formulate strategies that increase employee job satisfaction. Such efforts are expected to reduce employee turnover intention and actual turnover, generating significant benefits to organisations, especially in talent retention and reduced hiring costs. 


\section{References}

Aguiar do Monte, P. (2012). Job dissatisfaction and labour turnover: evidence from Brazil. The International Journal of Human Resource Management, 23(8), 1717-1735. doi:10.1080/09585192.2011.605071

Ajzen, I. (1991). The theory of planned behavior. Organizational Behavior and Human Decision Processes, 50(2), 179-211. doi:https://doi.org/10.1016/0749$\underline{5978(91) 90020-\mathrm{T}}$

Alatawi, M. (2017). Can transformational managers control turnover intention? SA Journal of Human Resource Management, 15.

Armstrong, M. a. (2006). A handbook of human resource management practice (10th ed.. ed.): London ; Philadelphia : Kogan Page.

Avolio, B. J., Waldman, D. A., \& Yammarino, F. J. (1991). Leading in the 1990s: The Four I's of Transformational Leadership. Journal of European Industrial Training, 15(4). doi:10.1108/03090599110143366

Barnett, K., McCormick, J., \& Conners, R. (2001). Transformational leadership in schools Panacea, placebo or problem? Journal of Educational Administration, 39(1), 2446. doi:10.1108/09578230110366892

Bass. (1997). Does the Transactional-Transformational Leadership Paradigm Transcend Organizational and National Boundaries? American Psychologist, 52(2), 130-139. doi:10.1037/0003-066X.52.2.130

Bass, B. M. (1985). Leadership and performance beyond expectations / Bernard M. Bass. New York : London: Free Press ; Collier Macmillan.

Bass, B. M. (1990). From Transactional to Transformational Leadership: Learning to Share the Vision. Organizational Dynamics, 18(3), 19-31.

Bass, B. M. (1998). Transformational Leadership: Industrial, Military, and Educational Impact: Lawrence Erlbaum Associates, Incorporated.

Bass, B. M., \& Avolio, B. J. (1993). TRANSFORMATIONAL LEADERSHIP AND ORGANIZATIONAL CULTURE. Public Administration Quarterly, 17(1), 112121. 
Bass, B. M., \& Avolio, B. J. (1994). Improving Organizational Effectiveness Through Transformational Leadership: SAGE Publications.

Bass, B. M. a. (2006). Transformational Leadership (2nd edition. ed.): Mahwah : Taylor \&amp; Francis Group.

Berson, Y., \& Linton, J. D. (2005). An examination of the relationships between leadership style, quality, and employee satisfaction in R\&amp;D versus administrative environments. R\&amp;D Management, 35(1), 51-60. doi:10.1111/j.14679310.2005.00371.x

Bono, J. E., \& Judge, T. A. (2003). Self-concordance at work: Toward understanding the motivational effects of transformational leaders. Academy of Management Journal, 46(5), 554. doi:10.2307/30040649

Buchanan, K. (2006). Job Performance and Satisfaction Retrieved from http://ezinearticles.com/?Job-Performance-and-Satisfaction\&id=290072

Burns, J. M. G. (1978). Leadership: Harper \& Row.

Bycio, P., Hackett, R. D., \& Allen, J. S. (1995). Further assessments of Bass's (1985) conceptualization of transactional and transformational leadership. Journal of Applied Psychology, 80(4), 468-478. doi:10.1037/0021-9010.80.4.468

Cotton, J. L., \& Tuttle, J. M. (1986). Employee Turnover: A Meta-Analysis and Review with Implications for Research. The Academy of Management Review, 11(1), 5570. doi:10.2307/258331

De Winne, S., Marescaux, E., Sels, L., Van Beveren, I., \& Vanormelingen, S. (2018). The impact of employee turnover and turnover volatility on labor productivity: a flexible non-linear approach. The International Journal of Human Resource Management, 1-31. doi:10.1080/09585192.2018.1449129

Donald, B. (2017). Leadership and Job Satisfaction: Adjunct Faculty at a For-Profit University. International Journal of Psychology and Educational Studies, 4(3), 53-63. doi:10.17220/ijpes.2017.03.006

Dunham-Taylor, J. (1995). Identifying the Best in Nurse Executive Leadership:: Part2, Interview Results. Journal of Nursing Administration, 25(7), 24-31.

Dupré, K. E., \& Day, A. L. (2007). The effects of supportive management and job quality on the turnover intentions and health of military personnel. Human Resource Management, 46(2), 185-201. doi:10.1002/hrm.20156 
George, J. M. a. (2012). Understanding and managing organizational behavior (6th ed.. ed.): Upper Saddle River, NJ ; Harlow : Pearson Prentice Hall.

Harhara, A. S., Singh, S. K., \& Hussain, M. (2015). Correlates of employee turnover intentions in oil and gas industry in the UAE. International Journal of Organizational Analysis, 23(3), 493-504.

Hoppock, R. (1935). Job Satisfaction: Harper.

Howell, J. M., \& Avolio, B. J. (1993). Transformational leadership, transactional leadership, locus of control, and support for innovation: Key predictors of consolidated-business-unit performance. Journal of Applied Psychology, 78(6), 891-902. doi:10.1037/0021-9010.78.6.891

Hughes, L. W., Avey, J. B., \& Nixon, D. R. (2010). Relationships Between Leadership and Followers' Quitting Intentions and Job Search Behaviors. Journal of Leadership \& Organizational Studies, 17(4), 351-362. doi:10.1177/1548051809358698

Ivancevich, J. M., Gibson, J. L., \& Konopaske, R. (2011). Organizations: Behavior, Structure, Processes: McGraw-Hill Education.

Khalid, N., Pahi, M. H., \& Ahmed, U. (2016). Loosing Your Best Talent: Can Leadership Retain Employees? The Dilemma of the Banking Sector of Hyderabad Sindh, Pakistan: A Mediation Investigation. International Review of Management and Marketing, 6(3).

Kirkbride, P. (2006). Developing transformational leaders: the full range leadership model in action. Industrial and Commercial Training, 38(1), 23-32.

Koh, W. L., Steers, R. M., \& Terborg, J. R. (1995). The effects of transformational leadership on teacher attitudes and student performance in Singapore. Journal of Organizational Behavior, 16(4), 319-333.

Krishnan, V. R. (2005). Leader-Member Exchange, Transformational Leadership, and Value System. . EJBO - Electronic Journal of Business Ethics and Organization Studies, 10(1), 14-21.

Lambert, E. G., Lynne Hogan, N., \& Barton, S. M. (2001). The impact of job satisfaction on turnover intent: a test of a structural measurement model using a national sample of workers. The Social Science Journal, 38(2), 233-250. doi:10.1016/S0362-3319(01)00110-0

Locke, E. A. (1969). What is job satisfaction? Organizational Behavior and Human Performance, 4(4), 309-336. doi:https://doi.org/10.1016/0030-5073(69)90013-0 
Matthews, M., Carsten, M. K., Ayers, D. J., \& Menachemi, N. (2018). Determinants of turnover among low wage earners in long term care: the role of manageremployee relationships (Vol. 39).

Meyer, J. P., Allen, N. J., \& Smith, C. A. (1993). Commitment to Organizations and Occupations: Extension and Test of a Three-Component Conceptualization. Journal of Applied Psychology, 78(4), 538-551.

Mobley, W. H. (1977). Intermediate linkages in the relationship between job satisfaction and employee turnover. Journal of Applied Psychology, 62(2), 237-240. doi:10.1037/0021-9010.62.2.237

Moradi, E., Almutairi, D. O., Idrus, D., \& Emami, R. (2013). The influence of organizational learning culture on job satisfaction among academic staff. Journal of Global Management, 5(1), 56-66.

Nemanich, L. A., \& Keller, R. T. (2007). Transformational leadership in an acquisition: A field study of employees. The Leadership Quarterly, 18(1), 49-68. doi:https://doi.org/10.1016/j.leaqua.2006.11.003

Newstrom, J. W., \& Davis, K. (2002). Organizational behavior : human behavior at work (11th. edition. ed.): Boston : McGraw-Hill/Irwin.

Noureen, R., \& Abbas, M. (2017). Can Employee Turnover Intentions Be Averted? Evaluation of Role of Job Satisfaction on the Relationship of Leader Member Exchange Dimensions and Employee Turnover Intentions. . Journal of Engineering and Applied Sciences, 12(8), 2238-2247.

Park, S. M., Joaquin, M. E., Min, K. R., \& Ugaddan, R. G. (2018). Do Reform Values Matter? Federal Worker Satisfaction and Turnover Intention at the Dawn of the Trump Presidency. The American Review of Public Administration, 48(6), 506521. doi:10.1177/0275074017706674

Podsakoff, P. M., Mackenzie, S. B., \& Bommer, W. H. (1996). Transformational leader behaviors and substitutes for leadership as determinants of employee satisfaction, commitment, trust, and organizational citize. Journal of Management, 22(2), 259298. doi:10.1016/S0149-2063(96)90049-5

Pravichai, S., \& Ariyabuddhiphongs, V. (2018). Transformational leadership and turnover intention: the mediating effects of right speech (Samma Vaca) and trust in the leader. Journal of Management, Spirituality \& Religion, 15(3), 253-272. doi:10.1080/14766086.2017.1417892 
Racz, S. (2000). Finding the Right Talent Through Sourcing and Recruiting.(overcoming employee turnover)(Statistical Data Included). Strategic Finance, 82(6), 38.

Robbins, S. P., \& Coulter, M. (2012). Management: Pearson.

Sakiru, O. K., Othman, J., Silong, A. D., Silva, J. L., \& Kareem, S. D. (2013). Review of leadership theories and organizational performances. International Business Management, 7(1), 50-54. doi:10.3923/ibm.2013.50.54

Sang Long, C., Yean Thean, L., Wan Ismail, W. K., \& Jusoh, A. (2012). Leadership Styles and Employees' Turnover Intention: Exploratory Study of Academic Staff in a Malaysian College (Vol. 19).

Shamir, B., House, R. J., \& Arthur, M. B. (1993). THE MOTIVATIONAL EFFECTS OF CHARISMATIC LEADERSHIP: A SELF-CONCEPT BASED THEORY. Organization Science, 4(4), 577-594.

Smith, D. B., \& Shields, J. (2013). Factors Related to Social Service Workers' Job Satisfaction: Revisiting Herzberg's Motivation to Work. Administration in Social Work, 37(2), 189-198. doi:10.1080/03643107.2012.673217

Spector, P. E. (1997). Job Satisfaction : Application, Assessment, Causes, and Consequences. Thousand Oaks, Calif: SAGE Publications, Inc.

Sun, R., \& Wang, W. (2017). Transformational leadership, employee turnover intention, and actual voluntary turnover in public organizations. Public Management Review, 19(8), 1124-1141. doi:10.1080/14719037.2016.1257063

Tae Heon, L. E. E., Gerhart, B., Weller, I., \& Trevor, C. O. (2008). UNDERSTANDING VOLUNTARY TURNOVER: PATH-SPECIFIC JOB SATISFACTION EFFECTS AND THE IMPORTANCE OF UNSOLICITED JOB OFFERS. Academy of Management Journal, 51(4), 651-671. doi:10.5465/AMJ.2008.33665124

Tett, R. P., \& Meyer, J. P. (1993a). Job satisfaction, organizational commitment, turnover intention, and turnover: Path analyses based on meta-analytical findings. Personnel Psychology, 46(2), 259.

Tett, R. P., \& Meyer, J. P. (1993b). JOB SATISFACTION, ORGANIZATIONAL COMMITMENT, TURNOVER INTENTION, AND TURNOVER: PATH ANALYSES BASED ON META-ANALYTIC FINDINGS. Personnel Psychology, 46(2), 259-293. doi:10.1111/j.1744-6570.1993.tb00874.x 
Van Dick, R., Christ, O., Stellmacher, J., Wagner, U., Ahlswede, O., Grubba, C., . . . Tissington, P. A. (2004a). Should I Stay or Should I Go? Explaining Turnover Intentions with Organizational Identification and Job Satisfaction *. British Journal of Management, 15(4), 351-360. doi:10.1111/j.1467-8551.2004.00424.x

Van Dick, R., Christ, O., Stellmacher, J., Wagner, U., Ahlswede, O., Grubba, C., . . . Tissington, P. A. (2004b). Should I Stay or Should I Go? Explaining Turnover Intentions with Organizational Identification and Job Satisfaction*. British Journal of Management, 15(4), 351-360. doi:10.1111/j.1467-8551.2004.00424.x

Walumbwa, F. O., Lawler, J. J., Avolio, B. J., Wang, P., \& Shi, K. (2005). Transformational leadership and work-related attitudes: the moderating effects of collective and self-efficacy across cultures. Journal of Leadership \& Organizational Studies, 11, 2+.

Weiss, H. M. (2002). Deconstructing job satisfaction: Separating evaluations, beliefs and affective experiences. Human Resource Management Review, 12(2), 173-194. doi:https://doi.org/10.1016/S1053-4822(02)00045-1

Worthy, K., Dawson, R. M., \& Tavakoli, A. S. (2020). doi:10.3928/01484834-2020012203

Yammarino, F. J., \& Bass, B. M. (1990). Long-term forecasting of transformational leadership and its effects among naval officers: Some preliminary findings: Leadership Library of America. 